\title{
Effects of purified glycerin in balanced diets of chicken broilers treated from 22 to 42 days of age ${ }^{1}$
}

\section{Glicerina purificada em dietas balanceadas para frangos de corte dos 22 aos 42 dias de idade ${ }^{1}$}

\author{
Mônica Calixto da Silva ${ }^{2 *}$; Roberta Gomes Marçal Vieira Vaz ; Kênia Ferreira \\ Rodrigues $^{3}$; Gerson Fausto da Silva ${ }^{3}$; Luciano Fernandes Sousa ${ }^{3}$; Flávia Luzia \\ Rodrigues Fonseca ${ }^{4}$; Carla Fonseca Alves Campos; ${ }^{4}$ Wescley Faccini Augusto ${ }^{2}$; \\ Iberê Pereira Parente ${ }^{5}$; Latóya de Sousa Bezerra ${ }^{6}$
}

\begin{abstract}
The aim of this study was to investigate the effects of including purified glycerin in the diets of broilers from 22 to 42 days of age. Eighty Cobb $500 \circledR$ lineage broilers were distributed in a completely randomized design (CRD) to one of four treatment groups $(0,2,4$ and $6 \%$ of purified glycerin inclusion in feed) and five replicates of four birds. The birds were evaluated for performance (weight gain, feed intake and feed conversion); carcass yield; special cuts yield (thigh, drumstick and breast); muscle colour $\left(\mathrm{L}^{*}=\right.$ lightness, $\mathrm{a}^{*}=$ redness, $\mathrm{b}^{*}=$ yellowness $)$; and crude protein, ether extract and moisture content of the breast muscle. Inclusion of purified glycerin in the diet did not affect $(p>0.05)$ any of the growth performance indicators, which demonstrated the technical feasibility of including up to $6 \%$ glycerin in the diet. Similarly, there was no effect on carcass yield; special-cut yields; muscle colour $\left(\mathrm{L}^{*}=\right.$ lightness, $\mathrm{a}^{*}=$ redness, $\mathrm{b}^{*}=$ yellowness $)$; or crude protein, ether extract and moisture content of breast muscle. The inclusion of purified glycerin at up to $6 \%$ in the diet proved to be feasible in broilers treated from 22 to 42 days of age.
\end{abstract}

Key words: Biodiesel by-products. High-energy feed. Meat quality. Growth performance.

\section{Resumo}

Objetivou-se neste trabalho avaliar os efeitos da inclusão de glicerina purificada em dietas balanceadas para frangos de corte dos 22 aos 42 dias de idade. Foram utilizados 80 frangos de corte, da linhagem Cobb $500^{\circledR}$, distribuídos em delineamento experimental inteiramente casualizado (DIC), com quatro tratamentos (0, 2, 4 e $6 \%$ de inclusão de glicerina purificada) e cinco repetições de quatro aves. Foram avaliados o desempenho (ganho de peso, consumo de ração e conversão alimentar), rendimentos de carcaça e cortes nobres (coxa, sobrecoxa e peito), a coloração ( $L^{*}=$ Luminosidade, $a^{*}$

${ }^{1}$ Parte da Tese de Doutorado da primeira autora.

2 Discentes de Pós-Doutorado, Programa de Pós-graduação em Ciência Animal Tropical, Universidade Federal do Tocantins, UFT, Araguaína, TO, Brasil.E-mail: monicalixto_@hotmail.com; wescleyfaccini@hotmail.com

3 Profs. Drs., Departamento de Zootecnia da Escola de Medicina Veterinária e Zootecnia, UFT, Araguaína, TO, Brasil. E-mail: betagmvvaz@yahoo.com.br; rodrigueskf@mail.uft.edu.br; gerson@mail.uft.edu.br; luciano.sousa@mail.uft.edu.br

${ }^{4}$ Discentes de Doutorado, Programa de Pós-Graduação em Ciência Animal Tropical, UFT, Araguaína, TO, Brasil. E-mail: flrf@ outlook.com; carlafazoo@hotmail.com

5 Prof., Instituto Federal de Educação, Ciência e Tecnologia do Maranhão. Presidente Dutra, MA, Brasil. E-mail: iberepereira@ hotmail.com

${ }^{6}$ Discente de Mestrado, Programa de Pós-Graduação em Ciência Animal Tropical, UFT, Araguaína, TO, Brasil. E-mail: latoyanina@hotmail.com

* Author for correspondence 
$=$ teor de vermelho e $\mathrm{b}^{*}=$ teor de amarelo) e os teores de proteína bruta, extrato etéreo e umidade da carne do peito. Os níveis de inclusão de glicerina purificada nas dietas não influenciaram ( $\mathrm{p}>0,05)$ nenhuma das características de desempenho, o que evidenciou a viabilidade técnica de inclusão de até $6 \%$ do alimento. Da mesma forma, não houve efeito sobre os rendimentos de carcaça e cortes nobres, coloração da carne ( $\mathrm{L}^{*}=$ Luminosidade, $\mathrm{a}^{*}=$ teor de vermelho e $\mathrm{b}^{*}=$ teor de amarelo) e nos teores de proteína bruta, extrato etéreo e umidade. A inclusão de glicerina purificada mostrou-se viável em até $6 \%$ em dietas balanceadas para frangos de corte dos 22 aos 42 dias de idade.

Palavras-chave: Alimento energético. Coprodutos do biodiesel. Desempenho produtivo. Qualidade da carne.

\section{Introduction}

Biodiesel production from oils and fats of vegetable or animal origin generates glycerin as a by-product, a substance high in energy (HENZ et al., 2014; LAMMERS et al., 2008; SWIATKIEWICZ; KORELESKI; 2009) with potential for use in broiler chicken feed at different stages of production (CERRATE et al., 2006; GUERRA et al., 2011; SEHU et al., 2013).

The potential use of glycerin as a feed additive is related to its high metabolisable energy value. According to Oliveira et al. (2013), when compared to the energy of the glycerin may be considered as a food birds because it has a good gross energy content, highly metabolizable.

In addition, the simple chemical structure and the low molecular weight of glycerin results in its efficient absorption by diffusion into the intestinal lumen (LIMA et al., 2014; MIN et al., 2010). Consequently, inclusion of glycerin in broiler feed may enhance the ingestion of food, due to its high absorption efficiency.

A study conducted by Topal and-Ozdogan (2013) investigated the effect of different levels of glycerin $(0,40$ and $80 \mathrm{~g} / \mathrm{kg}$ of feed, corresponding to 0,4 and $8 \%$, respectively) on growth performance, organ weights and chemical composition of the meat in Ross broilers treated from 1 to 42 days of age. Based on their findings, they concluded that inclusion of glycerin at 4 or $8 \%$ in feed can be used without compromising animal performance.

Similarly, McLea et al. (2011) examined different levels of glycerin $(3.3,6.7$ and 10\%) in broiler diets and found that inclusion of up to $6.7 \%$ did not negatively affect growth performance or feed digestibility.

Before using glycerin in animal feed, it is important to establish the precise chemical and nutritional composition of each sample. According to Jung and Batal (2011), wide variation in nutritional composition and contamination by methanol may limit its use in poultry feed. A further concern, according to Cerrate et al. (2006), is the high level of potassium, which may cause problems such as wet litter or electrolyte imbalance in the diet. High levels of minerals may exceed the nutritional requirements of poultry, resulting in reduced food intake, increased water intake and thus, higher bed humidity (CERRATE et al., 2006; GIANFELICI et al., 2011).

Studies investigating the effects of different glycerin levels in the diets of broilers at different stages of production, including effects on meat quality, can make a valuable contribution to considerations of the use of glycerin on a commercial scale. In view of this, the purpose of this study was to evaluate the effects of including glycerin in diets of broilers treated from 22 to 42 days of age.

\section{Material and Methods}

The experiment was conducted in the Poultry Sector of the School of Veterinary Medicine and Animal Science, Federal University of Tocantins, Araguaína, during the period February $15^{\text {th }}$ to March $7^{\text {th }}$ 2014. The study was conducted in accordance with the rules of the Ethics in Animal Use Committee, 
Federal University of Tocantins (CEUA-UFT) under the protocol number 23101.000830/2014-16.

Eighty male broilers of the Cobb 500® lineage were used in the study. Birds were housed in an experimental shed with concrete floor, covered with Babassu straw. The birds were housed in cages of $0.5 \times 0.5 \times 0.5 \mathrm{~m}$, with gutter feeders and drinkers. Replenishing of feeders, and cleaning and refilling of drinkers were performed twice daily, ensuring free access to water and feed throughout the experimental period.

Environmental conditions inside the facility during the experimental period, specifically temperature and relative humidity, were monitored and recorded daily every 5 min using HOBO Data Loggers OnSet ${ }^{\circledR}$ ware Version 3.4.1. Monitors were placed halfway up the cages.

The birds were fed a formulated diet to meet the nutritional requirements according to Rostagno et al. (2011) until 21 days of age. At 22 days of age, broilers with an average weight of $996 \pm$ $66.53 \mathrm{~g}$ were homogenised. Birds were assigned to treatment groups using a completely randomized design (CRD). There were four treatments groups $(0,2,4$ and $6 \%$ purified glycerin inclusion), with five replicates of four birds in each group.

The experimental diets were prepared based on the chemical composition of the purified glycerin (Table 1) and the nutritional requirements for medium-performance male broilers recommended by Rostagno et al. (2011) (Table 2).
The following parameters were determined: feed intake (FI); weight gain (WG); feed conversion ratio (FCR); final weight (FW); carcass yield (CY); special-cut yield (thigh, drumstick and breast); colour of breast muscle $\left(\mathrm{L}^{*}=\right.$ lightness, $\mathrm{a}^{*}=$ redness, $\mathrm{b}^{*}=$ yellowness); and composition of breast muscle (crude protein, ether extract and moisture content).

The broilers were weighed at the beginning and end of the treatment period to determine WG. FI was based on the amount of feed supplied and that remaining in the feeders. FCR was the ratio of feed intake to weight gain.

At 42 days of age, two broilers per repetition, with body weights within $\pm 5 \%$ of the average, were fasted for $12 \mathrm{~h}$ and then slaughtered by cervical dislocation (total of 40 birds). Birds were then subjected to bleeding, scalding, plucking and evisceration procedures. Relative weights of whole carcases (with legs, neck and head) and special cuts (thigh, drumstick and breast) were determined.

Breast meat (with bone, skin, ligaments and fat removed) was evaluated for $\mathrm{pH}$ and colour using the CIELAB system $\left(L^{*}=\right.$ lightness, $a^{*}=$ redness, $b^{*}$ $=$ yellowness) with a colorimeter $\left(\right.$ Chroma meter $\left.{ }^{\circledR}\right)$. Readings were performed at three different points of the musculature.

Crude protein, ether extract and moisture content of breast meat were determined. Breast muscle (minus bone, skin, ligaments and fat) was crushed, pre-dried at $55{ }^{\circ} \mathrm{C}$ and ground in a knife mill (sieve size $2 \mathrm{~mm}$ ). Samples were then analysed according to the method of Silva and Queiroz (2002). 
Table 1. Composition of purified glycerin used in the formulation of experimental diets. ${ }^{3}$

\begin{tabular}{|c|c|}
\hline Nutrients-and-energy & Purified-glycerin $^{1}$ \\
\hline Crude-protein $(\%)^{2}$ & 0.23 \\
\hline Metabolizable-energy $(\mathrm{kcal} / \mathrm{kg})^{2}$ & 3560 \\
\hline Dry-matter $(\%)^{3}$ & 89.98 \\
\hline Ether-extract $(\%)^{3}$ & 1.19 \\
\hline Mineral content $(\%)^{3}$ & 7.86 \\
\hline Methanol $(\mathrm{g} / \mathrm{kg})^{3}$ & Less-than 0.1 \\
\hline Glycerol $(\%)^{3}$ & 80.4 \\
\hline $\mathrm{NaCl}(\%)^{3}$ & 7.47 \\
\hline $\mathrm{Na}(\%)^{3}$ & 2.96 \\
\hline
\end{tabular}

${ }^{1}$ Glycerin from the processing of soybeans, sold in southern Brazil.

${ }^{2}$ Rostagno et al. (2011).

${ }^{3}$ Approximate values supplied by manufacturer.

Table 2. Composition of experimental diets fed to broilers from 22 to 42 days of age.

\begin{tabular}{lcccc}
\hline \multirow{2}{*}{ Ingredients } & \multicolumn{3}{c}{ Levels of purified glycerin (\%) } \\
\cline { 2 - 4 } & 0 & 2 & 4 & 6 \\
\hline Cornmeal & 64.039 & 61.843 & 59.647 & 57.451 \\
Soybeanmeal (45\%) & 29.434 & 29.821 & 30.206 & 30.592 \\
Purifiedglycerin & 0.000 & 2.000 & 4.000 & 6.000 \\
Dicalciumphosphate & 1.172 & 1.174 & 1.177 & 1.179 \\
Soybeanoil & 3.078 & 3.040 & 3.005 & 2.968 \\
Limestone & 0.817 & 0.815 & 0.812 & 0.810 \\
Salt & 0.450 & 0.302 & 0.154 & 0.006 \\
DL-Methionine & 0.248 & 0.250 & 0.253 & 0.255 \\
L-LisineHCl & 0.214 & 0.207 & 0.199 & 0.192 \\
L-Threonine & 0.048 & 0.048 & 0.047 & 0.047 \\
Mineral andvitamin supplement ${ }^{1}$ & 0.500 & 0.500 & 0.500 & 0.500 \\
Total & 100.00 & 100.00 & 100.00 & 100.00 \\
\hline & Calculated nutritional composition & & \\
\hline ME (kcal/kg) & 3125 & 3125 & 3125 & 3125 \\
Crudeprotein (\%) & 18.75 & 18.75 & 18.75 & 18.75 \\
Calcium (\%) & 0.685 & 0.685 & 0.685 & 0.685 \\
AvailablePhosphorus (\%) & 0.320 & 0.320 & 0.320 & 0.320 \\
DigestibleLysine (\%) & 1.044 & 1.04 & 1.044 & 1.044 \\
Methionine + DigestibleCystine (\%) & 0.762 & 0.762 & 0.762 & 0.762 \\
DigestibleMethionine (\%) & 0.501 & 0.502 & 0.503 & 0.504 \\
DigestibleThreonine (\%) & 0.678 & 0.678 & 0.678 & 0.678 \\
Sodium (\%) & 0.197 & 0.197 & 0.197 & 0.197 \\
Potassium (\%) & 0.725 & 0.725 & 0.726 & 0.727 \\
Chlorine (\%) & 0.322 & 0.232 & 0.143 & 0.053 \\
Electrolyte balance (mEq/kg) ${ }^{2}$ & 180.3 & 205.7 & 231.0 & 256.7 \\
\hline Compsitis & 178.00 & & \\
\hline
\end{tabular}

${ }^{1}$ Composition/ton: FolicAcid: $150.00 \mathrm{mg}$; Cobalt: $178.00 \mathrm{mg}$; Copper: $2675.00 \mathrm{mg}$; Choline: $120.00 \mathrm{~g}$; Colistin: 2,000.00 mg; Iron: $11.00 \mathrm{~g}$; Iodine: $535.00 \mathrm{mg}$; Manganese: $31.00 \mathrm{~g}$; Mineral content: $350.00 \mathrm{~g}$; Niacin: 7,200.00 mg; Nicarbazin: $24.00 \mathrm{~g}$; CalciumPantothenate: $2400.00 \mathrm{mg}$; Selenium: $60.00 \mathrm{mg}$; Vitamin A: 1,920,000.00 IU; Vitamin B1: $300.00 \mathrm{mg}$; Vitamin B12: 3,600.00 mg; Vitamin B2: 1,200.00 mg; Vitamin B6: 450.00 mg; Vitamin D3: 360,000.00 IU; Vitamin E: 3,600.00 IU; Vitamin H: $18.00 \mathrm{mg}$; Vitamin K: $480.00 \mathrm{mg}$; Zinc: $22.00 \mathrm{~g}$.

${ }^{2}$ Calculated according to Mongin (1981): Electrolyte Balance $=\left(\mathrm{mg} / \mathrm{kg}\right.$ of dietary $\left.\mathrm{Na}^{+} / 22.990\right)+(\mathrm{mg} / \mathrm{kg}$ of dietary K$/ 39.102)-$ $(\mathrm{mg} / \mathrm{kg}$ of dietary $\mathrm{Cl} / 35.453)$. 
Data were subjected to tests for Normality tests (Cramer Von Mises) and homoscedasticity (Levene). Variables for which these assumptions were met were subjected to analysis of variance.

The variables were subjected to regression analysis using first- or second-order polynomial models, considering the inclusion level of purified glycerin as an independent variable. To check the equation for goodness of fit, Fischer's exact test, the Student's t-test for the model parameters $(\beta 0$, $\beta 1$ and $\beta 2)$ and the coefficient of determination $\left(\mathrm{R}^{2}\right.$ $=\mathrm{SS}$ regression $/ \mathrm{SS}$ total) were used, applying a significance level $\alpha=0.05$. Statistical analyses were performed with the aid of the SISVAR program.

\section{Results and Discussion}

Ambient conditions during the study included air temperatures which ranged from a maximum of $32.2^{\circ} \mathrm{C}$ to a minimum of $20.5^{\circ} \mathrm{C}$ (mean temperature $25.6^{\circ} \mathrm{C}$ ), and relative humidity of $78 \%$. Daily air temperature readings were within the recommended range considered comfortable throughout the trial period, which indicated that the broilers were within the thermoneutral zone (CORDEIRO et al., 2010; OLIVEIRA et al., 2006).

The average relative humidity value was above the range recommended for poultry. This may be explained by the trial period coinciding with a period of heavy rainfall in the region. It is possible that this did not affect broiler performance because the air temperature values were within the thermoneutral range.

Purified glycerin inclusion levels in diets did not affect $(p>0.05)$ FI, WG, FCR and broiler weight at 42 days of age (W42d) (Table 3). The lack of effect of glycerin levels on these parameters may be a result of experimental diets being formulated to be isoenergetic $(3125 \mathrm{kcal} / \mathrm{kg})$ and isoproteic (18.75\%), thus meeting the nutritional requirements of broilers in all treatment groups, irrespective of purified glycerin levels.

Table 3. Average feed intake (FI), weight gain (WG), feed conversion (FCR) and weight values at 42 days (W42d) in broilers treated from 22 to 42 days of age.

\begin{tabular}{|c|c|c|c|c|c|c|c|c|c|}
\hline \multirow{2}{*}{ Variables } & \multicolumn{4}{|c|}{ Purified glycerin inclusion level (\%) } & \multirow{2}{*}{ Mean } & \multicolumn{3}{|c|}{$\mathrm{P}$} & \multirow{2}{*}{$\begin{array}{l}\mathrm{CV}^{1} \\
(\%)\end{array}$} \\
\hline & 0 & 2 & 4 & 6 & & LE & $\mathrm{QE}$ & LD & \\
\hline FI (g) & 3141.8 & 3057.2 & 3063.4 & 3089.0 & 3087.85 & 0.837 & 0.645 & 0.532 & 4.12 \\
\hline WG $(\mathrm{g})$ & 1679.3 & 1620.5 & 1662.5 & 1612.3 & 1643.5 & 0.212 & 0.329 & 0.270 & 3.01 \\
\hline FCR $(\mathrm{g} / \mathrm{g})$ & 1.87 & 1.89 & 1.85 & 1.92 & 1.88 & 0.322 & 0.209 & 0.095 & 2.48 \\
\hline W42d (g) & 2684.8 & 2626.8 & 2670.5 & 2621.5 & 2650.9 & 0.272 & 0.348 & 0.280 & 3.96 \\
\hline
\end{tabular}

${ }^{\mathrm{I}}$ Coefficient of variation (\%).

$\mathrm{LE}=$ linear effect; $\mathrm{QE}=$ quadratic effect; $\mathrm{LD}=$ linearity deviation; $\mathrm{P}=$ probability of type $\mathrm{I}$ error.

Similar results were reported by Silva et al. (2012) in an investigation of increasing glycerin levels $(2.5,5.0,7.5$ and 10\%) in broiler diets. They found that the inclusion of 5\% had no effect on growth performance in broilers treated from 1 to 42 days of age. In a similar study, Sehu et al. (2013) evaluated dietary glycerin levels $(0,5$ and $10 \%$ ) in broilers treated from 1 to 42 days age and demonstrated that with 5 and $10 \%$ glycerin there was an increase in growth performance.
Contrasting results were obtained by Romano et al. (2014) who examined the effects of diets containing 2.5, 5.0, 7.5 and $10 \%$ glycerin. They concluded that broilers are capable of adequately metabolising glycerin in the diet at up to $7.5 \%$, but that undesirable metabolic changes may occur at higher levels.

According to Gianfelici et al. (2011), it is possible to use glycerin as an energy source for 
poultry nutrition, although it is difficult to avoid problems caused by excessive moisture in the bed. This is caused by constituent minerals present in the glycerin leading to increased wetting of the bedding (GUERRA et al., 2011).

In this study, it was observed that inclusion of purified glycerin did not affect $(\mathrm{p}>0.05)$ carcass, thigh, drumstick and breast relative weights from broilers slaughtered at 42 days of age (Table 4).

These results are in agreement with those observed by Silva et al. (2012), who found no effect of the inclusion of glycerin on carcass, thigh, drumstick and breast yields in broilers at 43 days old. According to these authors, glycerol may increase the deposition of breast protein by reducing gluconeogenesis from amino acids, caused by inhibition of the phosphoenolpyruvate carboxykinase enzyme.

It could therefore be anticipated that the increase in purified glycerin levels in the diets of broilers would alter breast yield. However, this response was not observed, indicating that the inclusion levels of purified glycerin in the diets did not reach sufficient magnitude to increase this variable.

Table 4. Average carcass (CY), thigh (TCY), drumstick (DSCY) and breast (BY) yields from broilers at 42 days of age.

\begin{tabular}{|c|c|c|c|c|c|c|c|c|c|}
\hline \multirow{2}{*}{ Variables } & \multicolumn{4}{|c|}{ Purified glycerin inclusion level (\%) } & \multirow{2}{*}{ Mean } & \multicolumn{3}{|c|}{$\mathrm{P}$} & \multirow{2}{*}{$\mathrm{CV}^{1}(\%)$} \\
\hline & 0 & 2 & 4 & 6 & & LE & $\mathrm{QE}$ & LD & \\
\hline CY (\%) & 83.93 & 84.32 & 85.05 & 84.15 & 84.34 & 0.458 & 0.128 & 0.309 & 1.06 \\
\hline TCY $(\%)$ & 12.64 & 12.77 & 12.27 & 13.01 & 12.64 & 0.620 & 0.090 & 0.054 & 3.57 \\
\hline $\operatorname{DSCY}(\%)$ & 13.54 & 13.80 & 13.48 & 13.48 & 13.56 & 0.733 & 0.766 & 0.524 & 6.22 \\
\hline BY (\%) & 31.87 & 31.97 & 32.49 & 31.36 & 31.99 & 0.759 & 0.183 & 0.255 & 3.78 \\
\hline
\end{tabular}

${ }^{1}$ Coefficient of variation (\%).

$\mathrm{LE}=$ linear effect; $\mathrm{QE}=$ quadratic effect; $\mathrm{LD}=$ linearity deviation; $\mathrm{P}=$ probability of type $\mathrm{I}$ error

It was observed that the inclusion levels of purified glycerin in the diets did not affect $(\mathrm{p}>$ $0.05)$ the average values of crude protein (CP), ether extract (EE) and moisture content $(\mathrm{M})$ in breast meat (Table 5). There was, however, an effect on the percentage of ash in the breast of broilers slaughtered at 42 days old.

Table 5. Average values of crude protein (CP), ether extract (EE), moisture (M) and ashes in the breast meat of broilers at 42 days of age.*

\begin{tabular}{|c|c|c|c|c|c|c|c|c|c|}
\hline \multirow{2}{*}{ Variables } & \multicolumn{4}{|c|}{ Purified glycerin inclusion level (\%) } & \multirow{2}{*}{ Mean } & \multicolumn{3}{|c|}{$\mathrm{P}$} & \multirow{2}{*}{$\begin{array}{l}\mathrm{CV}^{1} \\
(\%)\end{array}$} \\
\hline & 0 & 2 & 4 & 6 & & LE & $\mathrm{QE}$ & LD & \\
\hline $\mathrm{CP}(\%)$ & 21.41 & 20.51 & 21.20 & 21.81 & 21.22 & 0.453 & 0.189 & 0.500 & 5.09 \\
\hline $\mathrm{EE}(\%)$ & 5.12 & 5.63 & 5.57 & 5.30 & 5.40 & 0.744 & 0.210 & 0.794 & 4.32 \\
\hline $\mathrm{M}(\%)$ & 76.83 & 77.05 & 77.38 & 77.27 & 77.12 & 0.685 & 0.321 & 0.185 & 2.56 \\
\hline Ashes $(\%)$ & 1.45 & 1.38 & 1.30 & 1.23 & 1.34 & 0.001 & 0.291 & 0.006 & 3.53 \\
\hline
\end{tabular}

${ }^{1}$ Coefficient of variation (\%).

$\mathrm{LE}=$ linear effect; $\mathrm{QE}=$ quadratic effect $\mathrm{LD}=$ linearity deviation; $\mathrm{P}=$ probability of type $\mathrm{I}$ error

Equation: Ashes $(\%)=1.45-0.036 \mathrm{IL}\left(\mathrm{P}=0.001 ; \mathrm{r}^{2}=0.79\right)$; wherein IL = inclusion level of purified glycerine $(\%)$.

*Analyses were expressed based on organic matter. 
The results of analysis of breast meat in relation to moisture and crude protein were similar to those found by Topal and Ozdogan (2013), who examined increasing levels of glycerin in the feed of broilers and found no differences in these parameters. However, the authors observed a gradual reduction in the ether extract content of broilers fed diets containing 4 or $8 \%$ glycerin.

It was observed that the purified glycerin inclusion levels did not affect $(\mathrm{p}>0.05)$ lightness $\left(\mathrm{L}^{*}\right)$, redness $\left(\mathrm{a}^{*}\right)$ and yellowness $\left(\mathrm{b}^{*}\right)$ values in the breast meat of broilers slaughtered at 42 days of age (Table 6).

Table 6. Average lightness $\left(\mathrm{L}^{*}\right)$, redness $\left(\mathrm{a}^{*}\right)$ and yellowness $\left(\mathrm{b}^{*}\right)$ values in the breast meat of broilers at 42 days of age.

\begin{tabular}{|c|c|c|c|c|c|c|c|c|c|}
\hline \multirow{2}{*}{ Variables } & \multicolumn{4}{|c|}{ Purified glycerin inclusion level (\%) } & \multirow{2}{*}{ Mean } & \multicolumn{3}{|c|}{$\mathrm{P}$} & \multirow{2}{*}{$\begin{array}{l}\mathrm{CV}^{1} \\
(\%)\end{array}$} \\
\hline & 0 & 2 & 4 & 6 & & LE & $\mathrm{QE}$ & LD & \\
\hline $\mathrm{L}^{*}$ & 58.74 & 60.73 & 59.66 & 60.38 & 59.88 & 0.834 & 0.439 & 0.236 & 2.52 \\
\hline$a^{*}$ & 9.95 & 9.59 & 10.13 & 9.18 & 9.70 & 0.267 & 0.472 & 0.478 & 9.75 \\
\hline$b^{*}$ & 10.08 & 10.84 & 10.98 & 10.21 & 10.53 & 0.564 & 0.593 & 0.489 & 9.84 \\
\hline
\end{tabular}

${ }^{1}$ Coefficient of variation $(\%)$.

$\mathrm{LE}=$ linear effect; $\mathrm{QE}=$ quadratic effect $\mathrm{LD}=$ linearity deviation; $\mathrm{P}=$ probability of type $\mathrm{I}$ error.

In a similar study, Faria et al. (2013) evaluated different levels of glycerin in the feed of broiler chickens and observed an increase in redness and a change in the angle of colour tonality. According to the authors, the meat presented in general an orange colour, and with increasing levels of glycerin in the diet showed a tendency towards red colouration.

It was therefore speculated that glycerin could affect the colour of raw broiler breast meat. However, the results of this study indicated that increased inclusion of purified glycerin in diets was insufficient to influence pigmentation of raw broiler breast meat.

\section{Conclusion}

The inclusion of purified glycerin in feed at up to $6 \%$ proved to be feasible for broilers treated from 22 to 42 days of age.

\section{Acknowledgements}

Coordination for the Improvement Higher of Education Personnel - CAPES, for granting the scholarship, the Federal University of Tocantins UFT for the support and availability of facilities and the ASA-Norte Foods and GRANFORTE by the supply of raw material to carry out the experiments.

\section{References}

CERRATE, S.; YAN, F.; WANG, Z.; COTO, C.; SACAKLI, P.; WALDROUP, P. W. Evaluation of glycerine from biodiesel production as a feed ingredient for broilers. International Journal of Poultry Science, Faisalabad, v. 5, n. 11, p. 1001-1007, 2006.

CORDEIRO, M. B.; TINÔCO, I. F. F.; SILVA, J. N.; VIGODERIS, R. B.; PINTO, F. A. C.; CECON, P. R. Conforto térmico e desempenho de pintos de corte submetidos a diferentes sistemas de aquecimento no período de inverno. Revista Brasileira de Zootecnia, Viçosa, v. 39, n. 1, p. 217-224, 2010.

FARIA, P. B.; FIGUEIREDO, C. H.; LIMA, R. S.; NASCIMENTO, D. B.; SANTOS, C. C. S.; PINTO, A. M. B.; SILVA, J. L. Qualidade de carcaça e carne de frangos com uso de glicerina na alimentação. PUBVET, Londrina, v. 7, n. 24, Ed. 247, Art. 1631, 2013.

GIANFELICI, M.F.; RIBEIRO,A.M.L.; PENZJUNIOR, A. M.; KESSLER, A. M.; VIEIRAM. M.; MACHINSKY, T. Determination of apparent metabolizable energy of crude glycerin in broilers chickens. Brazilian Journal of Poultry Science, Campinas, v. 13, n. 4, p. 255-258, 2011. 
GUERRA, R. L. H.; MURAKAMI, A. E.; GARCIA, A. F. Q. M.; URGNANI, F. J.; MOREIRA, I.; PICOLI, K. P. Glicerina bruta mista na alimentação de frangos de corte (1 a 42 dias). Revista Brasileira de Saúde e Produção Animal, Salvador, v. 12, n. 4, p. 1038-1050, 2011.

HENZ, J. R.; NUNES, R. V.; EYNG, C.; SILVA, Y. L.; SCHONE, R. A.; OLIVEIRA, T. M. M.; BERWANGER, E.; SANGALI, C. P. Energia metabolizável da glicerina bruta para frangos de corte de diferentes idades. Semina: Ciências Agrárias, Londrina, v. 35, n. 6, p. 3393-3400, 2014.

JUNG, B.; BATAL, A. B. Nutritional and feeding value of crude glycerin for poultry. 2. Evaluation of feeding crude glycerin to broilers. Journal of Applied Poultry Research, Champaign, v. 20, n. 2, p. 514-527, 2011.

LAMMERS, P. J.; KERR, B. J.; HONEYMAN, M. S.; STALDER, K.; DOZIER, W. A.; WEBER, T. E.; KIDD, M. T.; BREGENDAHL, K. Nitrogen-corrected apparent metabolizable energy value of crude glycerol for laying hens. Poultry Science, Champaign, v. 87, n. 1, p. 104107, 2008.

LIMA, D. C.; TEIXEIRA NETO, M. V.; FELIX, A. P.; BORTOLO, M.; OLIVEIRA, S. G.; MAIORKA, A. Digestibilidade e energia metabolizável da glicerina em cães. Ciência Rural, Santa Maria, v. 8, n. 44, p. 14521456, 2014.

MCLEA, L.; BALL, M. E. E.; KILPATRICK, D.; ELLIOTT, C. The effect of glycerol inclusion on broiler performance and nutrient digestibility. British Poultry Science, London, v. 52, n. 3, p. 368-375, 2011.

MIN, Y. N.; YAN, F.; LIU, F. Z.; COTO, C.; WALDROUP, P.W. Glycerin-A new energy source for poultry. International Journal of Poultry Science, Faisalabad, v. 9, n. 1, p. 1-4, 2010.

MONGIN, P. Recent advances in dietary cation-anion balance: applications in poultry. Proceedings Nutrition Society, Cambridge, v. 40, n. 3, p. 285-294, 1981.

OLIVEIRA, D. D.; PINHEIRO, J. W.; OBA, A.; FONSECA, N. A. N. Desempenho de frangos de corte alimentados com glicerina pura. Semina Ciências Agrárias, Londrina, v. 34, n. 6, p. 4083-4092, 2013. Suplemento 2.
OLIVEIRA, R. F. M.; DONZELE, J. L.; ABREU, M. L. T.; FERREIRA, R. A.; VAZ, R. G. M. V.; CELLA, P. S. Efeitos da temperatura e da umidade relativa sobre o desempenho e o rendimento de cortes nobres de frangos de corte de 1 a 49 dias de idade. Revista Brasileira de Zootecnia, Viçosa, v. 35, n. 3, p. 797-803, 2006.

ROMANO, G. G.; MENTEN, J. F. M.; FREITAS, L. W.; LIMA, M. B.; PEREIRA, R.; ZAVARIZE, K. C.; DIAS, C. T. S. Effects of glycerol on the metabolism of broilers fed increasing glycerine levels. Brazilian Journal of Poultry Science, Campinas, v. 16, n. 1, p. 97-106, 2014.

ROSTAGNO, H. S.; ALBINO, L. F. T.; DONZELE, J. L.; GOMES, P. C.; OLIVEIRA, R. F.; LOPES, D. C.; FERREIRA, A. S.; BARRETO, S. L. T. Tabelas brasileiras para aves e suinos composição de alimentos e exigências nutricionais. 3. ed. Viçosa: UFV, Imprensa Universitária, 2011.252 p.

SEHU, A.; KUCUKERSAN, S.; COSKUN, B.; KOKSAL, B. H. Efects of graded levels of crude glycerine addition to diets on growth performance, carcass traits and economic efficiency in broiler chickens. Kafkas Universitesi Veteriner Fakultesi Dergisi, Kars, v. 19, n. 4, p. 569-574, 2013.

SILVA, C. L. S.; MENTEN, J. F. M.; TRALDI, A. B.; PEREIRA, R.; ZAVARIZE, K. C.; SANTAROSA, J. Glycerine derived from biodiesel production as a feedstuff for broiler diets. Brazilian Journal of Poultry Science, Campinas, v. 14, n. 3, p. 159-232, 2012.

SILVA, D. J.; QUEIROZ, A. C. Análise de alimentos: métodos químicos e biológicos. 3. ed. Viçosa: UFV, 2002. 165 p.

SWIATKIEWICZ, S.; KORELESKI, J. Effect of crude glycerin level in the diet of laying hens on egg performance and nutrient utilization. Poultry Science, Champaign, v. 88, n. 3, p. 615-619, 2009.

TOPAL, E.; OZDOGAN, M. Effects of glycerol on the growth performance, internal organ weights, and drumstick muscle of broilers. Journal of Applied Poultry Research, Champaign, v. 22, n. 1, p. 146-151, 2013. 